\title{
RELATIONS BETWEEN THE LUTHERAN CHURCH AND THE YOUNG MEN'S CHRISTIAN ASSOCIATION (YMCA) IN SLOVAKIA BETWEEN 1921 AND 1930
}

\author{
Ludvig, $D$. \\ Department of Physical Education and Sport, Faculty of Pharmacy, \\ Comenius University, Bratislava, Slovak Republic
}

The present paper explores the relation between churches and sports in the time period 1918-1948 in Slovakia. Mutual relations between the Lutheran Church and YMCA constitute a part of his research. The YMCA was an organisation established on Christian principles. At odds with the Catholic Church, the YMCA was fully accepted by the Lutheran Church; it was inspired by the means and methods of the YMCA, it used its buildings as well as personal resources. Lutherans advised their young people to take part in activities organised by the YMCA. The Association of Lutheran Youth (Zväz evanjelickej mládeže - SEM) actually became an independent member of the YMCA. The partnership between the Lutheran Church and the YMCA led to sports expansion in Slovakia.

Keywords: Young Men's Christian Association - YMCA, Lutheran Church, Association of Lutheran Youth, sport

\section{INTRODUCTION}

The attitude of the church towards sports and the place of sports within different churches (especially the Lutheran Church) after the establishment of Czechoslovakia in 1918 has not been much researched within the context of sports history in Slovakia. However the somewhat untraditional research of the sports life of churches continually shows the existence of relations between the church and sports activities. The YMCA was an organisation that made sports popular and introduced different sports in Slovakia, and was very open for cooperation. As a result, a firm relationship of mutual inspiration (not only in the field of sport) was created. According to statistical data, $12.80 \%$ of Slovak citizens identified themselves as Lutherans in 1921. In comparison with the Catholic Church with its $70.89 \%$ share in Slovak population, Lutherans represented a minority [14]. Being a smaller church, Lutherans tried to strengthen their members' sense of belonging and 
people's engagement in church activities. They strongly supported their youth and established the Association of Lutheran Youth with the aim of uniting the youth in one union operating through individual groups in different towns. The records of the activities of the Association established in 1921 reflect the Association's early cooperation with the YMCA (the history of the YMCA stretches back to 1919-1921). The YMCA was an organisation that was open to people of all nationalities, races and denominations and declared Christianity as its moral worldview [13, 16]. The YMCA's activities were of a broader range; however, for the purposes of our research we will only be covering the aspect of sports activities. The YMCA is considered the pioneer in introducing volleyball and basketball in Slovakia. Besides these sports it also offered great opportunities for other sports, e.g. athletics, football, fencing, table tennis, chess as well as an untraditional sport boxing. Besides, it organised swimming and skiing courses [13]. We need to emphasise that the YMCA was very popular in the towns where it had its local offices (Bratislava, Banská Bystrica, Lučenec) and its activities were well known among all sports fans.

Thanks to the positive relationship of the Lutheran Church with the YMCA, sports were spread in Lutheran youth in Slovakia. However these data were not published until now. In this paper we summarise the information about the relationship of the Lutheran Church with the YMCA, mainly in the field of sports.

\section{METHODS}

This article presents data on the history of the Lutheran Church and the YMCA in Slovakia in the time period 1921-1930. We analyse in detail historic documents describing the support for sports as a result of the cooperation between the Lutheran Church and the YMCA. We obtained the data from the official journal of the Association of Lutheran Youth - New Origin.

\section{RESULTS}

\section{Lutheran view of YMCA}

The Lutherans viewed YMCA very positively: "Our church and our youth greatly profit from the YMCA's activities. The Church does not have official contacts with the organisation; however, it observes their work closely. In spite of the fact that the YMCA's work is not based on a particular confession, by means of their practical work they introduce young people to a more spiritual and healthier lifestyle." [14] Lutheran youth was encouraged to play sports [1] and the YMCA provided a great space for doing so. The following statement from 1922 is proof of this: “Its [YMCA's] activities engage the whole man - his soul as well as his body because a healthy spirit dwells in a healthy body. As we will not be able to form our own organisation, we will have to rely on YMCA. It is already our obligation to become its member and support its activities." [2] Historical records show that the young generation of Lutherans was strongly encouraged to take an active part in the 
YMCA's sport activities. As we have already mentioned, intense cooperation was established between the YMCA and the Association of Lutheran Youth.

\section{Personal connections}

The most obvious form of cooperation of the YMCA and the Association of Lutheran Youth on a personal level can be seen in the fact that Dr. L. J. Karlovský, a representative of the former, was one of the four members of the National Council of the latter, holding the post of treasurer up to 1927. [3, 10] Dr. L. J. Karlovský was actually the President of YMCA! Also, priest Durovič (Secretary of the Association) was being invited to YMCA assemblies [3]. Moreover, Dr. Samuel Zoch, who was the bishop of the Lutheran Church at the time, also became one of the members of National Council of YMCA. Later on he was replaced by Fedor Ruppeldt [14]. The emphasis placed on cooperation is very obvious; the highest representatives of both institutions held important posts in the other institution's committees. In 1924, Dr. Štefan Osuský, the President of the Association and Ján Durovič, the Secretary, were elected as members of the National Committee of YMCA [5]. On the other hand, YMCA's representative V. Velkoborský became a member of the National Council of the Association [6].

\section{The YMCA's material help to the Association}

The Lutherans greatly appreciated the fact that the YMCA's buildings in Bratislava, Lučenec and Banská Bystrica became a meeting place for their youth [14]. The YMCA offered this form of help whenever the Lutherans needed a place to meet. They made the decision at the constitutive meeting of the association of Christian youth in Lučenec that took place in the YMCA building [4]. Young Lutherans in Lučenec were welcomed to use YMCA gym every Sunday for two hours. Lutheran representatives appreciated the willingness of the YMCA director in Lučenec because besides having a place for sports, they could also make use of YMCA's piano, electric lights and central heating [8].

Among other things, the YMCA building in Bratislava was a place where a tea party of the Unity of Lutheran Youth took place [7]. Participants of the Association's workshop were accommodated in YMCA as well [8]. The national assembly of the Association of Lutheran Youth in 1926 took place in the YMCA building in Lučenec [9, 15]. YMCA also offered financial help to the Association. In 1928 it made a financial contribution of 4,500 Czechoslovak koruna [14]. In August 1929, the first summer camp of Lutheran youth took place at the YMCA's camping site. Workers of the YMCA had their share in the successful event. Due to their positive experience with the camp the Lutherans organised another one in the next year in the village Oravský Podzámok. They made a resolution to build their own camping site similar to that of the YMCA [14]. 


\section{The accession of the Association of Lutheran Youth into the YMCA}

An important milestone in the relations of Lutherans and the YMCA was the visit of Emil Boleslav Lukáč, General Secretary of the Association of Lutheran Youth, to the global YMCA conference in Helsinki in 1926. He made contacts with all global youth organisations as well as Lutheran associations [14]. He periodically informed the readers of the Lutheran magazine Nový rod (New origin) about his trip. Under the influence of Lukáč's experiences, at the beginning of 1927 the Association started making plans for becoming a member of the World Union of Christian Associations. They appointed a preparatory committee that was supposed to deal with the issue [11]. At the national assembly in Banská Štiavnica in June 1927 the Association made a decision to access the world YMCA as an autonomous organisation $[14,12]$. Becoming a member of the global YMCA family was a logical consequence of the preceding five-year cooperation of the national YMCA and the Association of Lutheran Youth. This cooperation was a great contribution to the activities of the Lutheran Church in Slovakia, especially in the field of youth work.

\section{CONCLUSION}

Our research was successful in revealing the connections between the Lutheran Church and the YMCA and their importance in the history of Slovak physical education. Also, "church sports history" is enriched by one of the missing pieces of a puzzle. Our research findings show that the YMCA, an organisation with an important place in the sports history in Slovakia, was open for cooperation with everyone who was willing. Lutherans did not view the YMCA as a religious organisation; however, they appreciated its Christian values as well as the fact that by means of practical (sports) activities the YMCA developed both physical and spiritual wellbeing. The finding that the Lutheran Church closely cooperated with the YMCA and recommended its sport activities to its members is of high importance for our primary research on the relationship of the Church and sports. Many local Lutheran groups were inspired by the YMCA, but the YMCA was active only in three cities in Slovakia. However Slovakia is mainly a Catholic country and the Catholic Church had their own ways to support sports and didn't cooperate with the YMCA. The relationship between the Catholic Church and sports needs further study.

Acknowledgement: The author would like to thank all the employees of the Lutheran Church Archives, who enabled him to study the documents.

\section{REFERENCES}

1. New origin, 1,1922 , No. 7 , p. 135.

2. New origin, 2, 1922, No. 4, p. 118.

3. New origin, 3, 1923, No. 1, p. 8, 21.

4. New origin, 3, 1924, No. 7, p. 216.

5. New origin, 4. 1924, No. 4, p. 144.

6. New origin, 5, 1925, No. 2, p. 10.

40 
7. New origin, 5,1925 , No. 3 , p. 90.

8. New origin, 5, 1926, No. 5, p. 152, 192.

9. New origin, 5, 1926, No. 9, p. 242-3.

10. New origin, 6, 1927, No. 5 , p. 108.

11. New origin, 6, 1927, No. 7, p. 147.

12. New origin, 7, 1927, No. 1, p. 15.

13. PERÚTKA, J.: YMCA activities in Slovakia between 1918-1938. Bratislava: YMCA, 1997. p. 22, 25.

14. RUPPELDT, F.: Almanac of Slovak Lutheran Church from years 1919-1928 (up to 1930). Liptovský Sv. Mikuláš : Tranoscius, 1930. p. 22, 86, 296-300.

15. $Y M C A, 1,1926$, No. 5-6, p. 8.

16. YMCA Bratislava activities, 4, 1937, No. 3, p. 1-3.

Registered:April 15

Accepted: May 25

\author{
Mgr. Dalibor Ludvig \\ Department of Physical education and sport \\ Faculty of Pharmacy \\ Comenius University \\ Odbojárov 10 \\ 83232 Bratislava \\ Slovak Republic
}

\section{VZŤAHY EVANJELICKEJ CIRKVI A YMCA NA SLOVENSKU V ROKOCH $1921-1930$}

Ludvig, $D$.

Katedra telesnej výchovy a športu, Farmaceutická fakulta,

Univerzita Komenského, Bratislava

Príspevok prináša výsledky výskumu, ktorého oblast’ou skúmania je vzt’ah cirkví k športu v rokoch 1918-1948 na Slovensku. Dôsledkom toho je i prezentácia výskumu vzt’ahu evanjelickej cirkvi k YMCA a naopak. YMCA bola organizácia založená a fungujúca na základe krest’anských princípov. Na rozdiel od katolíckej cirkvi, evanjelická cirkev ju plne akceptovala, nechávala sa inšpirovat' prostriedkami a metódami jej práce, využívala jej budovy a boli prepojení aj personálne. Evanjelici svojej mládeži jednoznačne odporúčali návštevy YMCA. Dokonca prostredníctvom Združenia evanjelickej mládeže (SEM) evanjelická cirkev vstúpila do YMCA a stala sa jej autonómnym členom, čo následne prispelo k rozvoju športu na Slovensku.

Acta Facult. Pharm. Univ. Comenianae 58, 2011, p. 37 - 41. 